\title{
Review of the Study of Chinese and Foreign Management Accounting in 2015-2017
}

\author{
Lan Yang \\ School of Management, Jinan University, Guangzhou, China \\ Email: yanglan0602@126.com
}

How to cite this paper: Yang, L. (2020). Review of the Study of Chinese and Foreign Management Accounting in 2015-2017. American Journal of Industrial and Business Management, 10, 476-491. https://doi.org/10.4236/ajibm.2020.102032

Received: February 3, 2020

Accepted: February 25, 2020

Published: February 28, 2020

Copyright $\odot 2020$ by author(s) and Scientific Research Publishing Inc. This work is licensed under the Creative Commons Attribution International License (CC BY 4.0).

http://creativecommons.org/licenses/by/4.0/

\section{(c) (i) Open Access}

\begin{abstract}
This paper collates, summarizes and reviews 95 management accounting research literatures published in 6 academic journals and seven foreign journals between 2015 and 2017, and makes a comparative analysis of the research topics, research methods and application theories of management accounting. The results show that compared with the previous management accounting research in China, there have been significant changes in both research topics and research methods and applied theory. Research topics or research hot spots are becoming more diversified, research on Performance appraisal and motivation has increased significantly, research methods are more focused on database-based empirical research and experimental methodology and questionnaires, applied theory is more systematic and comprehensive, the subject background is gradually extended and cross-cutting. However, China's management accounting compared with foreign countries there is still a big gap; there is still a lot of room for development.
\end{abstract}

\section{Keywords}

Management Accounting, Research Hot Spots, Research Methods, Theories, Comparisons

\section{Introduction}

Management accounting was born in the early 20th century, in order to adapt to the objective requirements of social and economic development, the theory of tyro scientific management was produced. With the development of economy, management accounting has been widely promoted and applied in enterprises, and has made certain achievements, so that the degree of specialization and socialization of enterprises is higher, and then in the increasingly severe competi- 
tive environment to survive and develop. Management accounting, which entered our country in the 1970s, is a collection of information support systems and management control systems, and with the deepening and perfection of social and economic development and the innovation of enterprise management concept, its application in practice and academic research hotspots are constantly changing. Especially in the context of big data, the Internet and artificial intelligence to promote accounting transformation, a series of management accounting methods conducive to the creation of enterprise value are popular, and show the trend of integrated application, throughout every aspect of business management, to help enterprise managers to develop and implement organizational strategy, deep participation in management decision-making, Strengthen program control and performance management, become an increasingly important management tool for enterprises to improve value creation ability and build core competitiveness.

The Ministry of Finance (2014) issued the Guidance on the Comprehensive Promotion of the Construction of the Management Accounting System in accordance with the 12th Five-Year Plan for Accounting Reform and Development, and put forward the overall goal of building a management accounting system on October 27. However, the application of management accounting in our country has been in the primary stage, failed to give full play to the role of planning, decision-making, control and evaluation, theoretical research is lagging behind the needs of practice.

In recent years, with the rapid development of the economy, the role of management accounting is becoming more and more significant. Understanding the current situation and dynamics of management accounting in China, mastering hot issues, is of great practical significance to deepen the theoretical research and practical application of management accounting, and to realize the leap-forward development of Management Accounting in China. In recent years, the theory and practice of management accounting research at home and abroad have been deepening, the scope of research has been expanding, and the research methods have been increasing. So in recent years compared with foreign countries, China's management accounting research status, research hot spots, what the future research direction of the problem attracts many researchers.

Du et al. (2009) made a systematic summary of the management accounting research in China from 1997 to 2005. The central university of finance and economics task force (2010) made a certain summary of China's management accounting research methods, and $\mathrm{Hu}$ et al. (2011) made a certain combing of the development of the theory and practice of management accounting in China in the 30 years from 1978 to 2008. Meng et al. (2014) summarized the current situation of management accounting research in China. In view of this, this paper is based on 95 literatures in mainstream journals at home and abroad for comparative analysis to understand the current development of China's management accounting and the gap with foreign countries. 


\section{Literature Review}

\subsection{Research Topics}

For the compilation of the subject of management accounting research in China, the division of management accounting research topics in the review of current management accounting research in China basically evolved from the classification method of Shields (1997). Meng et al. (2014) compared the management accounting literature published in 200-2013 in china's academic journals, and compared them with the summary of Du et al. (2009) and Hesford et al. (2006). Although the article to a certain extent to domestic and foreign management accounting research made a comparative analysis, but Hesford et al. (2006) collated literature did not include the latest research dynamics, so that the article has certain limitations, of course, Hesford et al. (2006) on the domestic literature combing has a certain reference significance. Although Shields (2015) defines the subject of management accounting research as management accounting information (e.g. budgeting, performance appraisal, product cost or management accounting information characteristics) and management accounting practices (e.g. budgeting, measurement of performance, evaluation of performance, etc.), in order to achieve vertical comparability with previous research results, this paper is based on Meng et al. (2014). The classification of management accounting topics is based on the compilation of 95 management accounting documents collected for 2015-2017.

This paper will filter the selected 95 literature keywords into Excel, remove the management of accounting related keywords, and combine "Performance appraisal" and "Performance appraisal synonyms, with Excel PivotTable function statistical keyword frequency, and finally selected 16 high-frequency keywords, according to the size of the frequency of occurrence, sorted, Table 1 and Table 2 are shown.

According to the above two tables, Chinese keywords with higher frequency of budget management, Performance appraisal, strategic management accounting, budget management, cost management and internal control, etc., and English

Table 1. Chinese research literature on high-frequency keywords.

\begin{tabular}{|c|c|c|c|c|c|}
\hline Rank & Keyword & Frequency & Rank & Keyword & Frequency \\
\hline 1 & Budget management & 14 & 9 & Informatization & 8 \\
\hline 2 & $\begin{array}{l}\text { Strategic Management } \\
\text { Accounting }\end{array}$ & 12 & 10 & Big Data & 7 \\
\hline 3 & MAS & 10 & 11 & Non-financial indicators & 7 \\
\hline 4 & Performance appraisal & 10 & 12 & Management controls & 7 \\
\hline 5 & Chinese characteristics & 9 & 13 & $\begin{array}{c}\text { Activities-Based Cost } \\
\text { Method }\end{array}$ & 5 \\
\hline 6 & $\begin{array}{c}\text { Environmental } \\
\text { Management Accounting }\end{array}$ & 9 & 14 & Talent & 4 \\
\hline 7 & Internal controls & 8 & 15 & Performance management & 2 \\
\hline 8 & Cost management & 8 & 16 & AIS & 2 \\
\hline
\end{tabular}


Table 2. English research literature on high-frequency keywords.

\begin{tabular}{|c|c|c|c|c|c|}
\hline Rank & Keyword & Frequency & Rank & Keyword & Frequency \\
\hline 1 & Performance Measurement & 20 & 9 & $\begin{array}{l}\text { Corporate Social } \\
\text { Responsibility }\end{array}$ & 12 \\
\hline 2 & Information Systems & 18 & 10 & Control & 11 \\
\hline 3 & Performance & 18 & 11 & Budgeting & 11 \\
\hline 4 & Activity-based Costing & 17 & 12 & Strategic Management & 11 \\
\hline 5 & Supply Chain Management & 16 & 13 & Capital Budgeting & 9 \\
\hline 6 & $\begin{array}{l}\text { Management Control } \\
\text { Systems }\end{array}$ & 16 & 14 & Transfer Pricing & 5 \\
\hline 7 & Incentives & 16 & 15 & Balanced Score Card & 5 \\
\hline 8 & Risk Management & 14 & 16 & $\begin{array}{c}\text { Nonfinancial Performance } \\
\text { Measures }\end{array}$ & 5 \\
\hline
\end{tabular}

keywords with higher keyword slots are performance measurement, management control, activity-based costing, incentives, etc.

Through the analysis of keyword frequency, we can generally divide the research topics in the field of management accounting into 7 categories.

\subsubsection{Performance Appraisal}

The research of performance evaluation system is divided into two categories, one is the performance evaluation at the organizational level and the other is the performance evaluation at the individual level. The early performance evaluation research is mainly based on the performance evaluation system of the balanced scorecard (BSC) (Zhang, Yang, \& Gao, 2012) or the combination of BSC and EVA (economic value added, i.e. economic value added). For example, Liu and Chen (2007) take the case of the state-owned GP (general partner, or general partner) enterprise group and say that the advantage of the performance evaluation system combining BSC and EVA is not only to provide more accurate financial evaluation indicators, but also to take into account the impact of non-financial indicators. In recent years, the research on performance evaluation system involves less BSC, but the empirical research on the factors influencing enterprise performance increases, mainly studies the influence of inter-enterprise relations, equity structure and external environment on the performance of enterprises, such as Zheng et al. (2016) studies inter-enterprise family relations, and draws the relationship between families and enterprise performance. The conclusion of negative correlation was presented, and Chen and Huang (2016) confirmed the effectiveness of the share-trading reform through empirical research, and the reduction of the equity level contributed to the improvement of performance. There is also a part about the impact of "people" on corporate performance, including management and interpersonal relationships. Yang et al. (2014) research to travel sequence pattern in the different life cycle of the enterprise will have different effects on operating performance conclusions, Zhang et al. (2015) through 
empirical research found that the company's executives to enhance the company's control of the threshold effect, resulting in executives difficult to better deploy external resources through control, for this reason, the social With the relationship between executive control and enterprise performance has an inverted U-shaped adjustment effect.

The relevant literature at home and abroad mainly studies the application of management accounting in Performance appraisal. Enterprise Performance appraisal is the need of supervision, incentive and restraint, with the expansion of enterprise scale, there is an urgent need for a complete Performance appraisal system, and management accounting can be through the prediction of economic prospects, enterprise strategy, business decision-making and other evaluation, so it is imperative to apply management accounting to Performance appraisal. However, compared with the Russian research of foreign literature, most of the indexes of management accounting evaluation in China are copied in developed countries, which lack flexibility and Chinese characteristics in practical application. In recent years, there has been a new research on the system of management accounting evaluation index, including both financial indicators and non-financial indicators, and non-financial indicators have attracted the attention of Chinese scholars.

\subsubsection{Cost Management}

The relevant literature mainly studies the application of management accounting in cost management. In cost management, the application of management accounting can better manage and control the enterprise, increase the profits of enterprises, in which the operation cost method in the domestic research gradually in recent years, but in the actual application of enterprises is not ideal.

Zhou et al. (2012) introduced the ABC method as a change and innovation of management accounting, using field research methods to study the process nature, influencing factors and consequences of management accounting changes. He et al. (2014) put forward the theoretical system of evaluating environmental responsibility, based on the view that cost management is to optimize the allocation of resources, regard the environment as an optimized resource, and put forward its evaluation system based on KPI (key indicators of performance (Ji \& Su, 2016). Empirical research shows that the cost of environmental governance paid by enterprises is due to the existence of environmental regulatory system, not because the cost of environmental governance can bring profits to enterprises.

\subsubsection{Strategic Management}

The relevant literature mainly studies the method system of strategic management and its application. In recent years, with the rapid development of economy, the scale of enterprises has been expanding, thus increasing the uncertainty of the living environment, and it is necessary to accelerate the transition from traditional management accounting to strategic management accounting. 


\subsubsection{Environmental Management Accounting}

Compared with foreign countries, China pays more attention to the research of environmental management accounting, and the relevant literature mainly focuses on the role of environmental management accounting and the application of research. In recent years, people pay more and more attention to environmental problems, so environmental management accounting has become a new field of management accounting, so China's management accounting and the attention of enterprises, its implementation can enable enterprises to avoid violating environmental laws and regulations, protect the environment, make full use of enterprise resources, improve enterprise performance, so that enterprises can operate sustainably.

\subsubsection{Budget Management}

The relevant literature is mainly to study the development of budget management. Budget management is essentially a forecast of enterprises in the next business cycle, business management situation cannot be fully in line with the forecast, with great uncertainty. Most foreign research on budget management focuses on budget objectives, which can bring budget management closer together with corporate strategy and play a better role.

\subsubsection{Internal Control}

The relevant literature is mainly on the application of internal control. Management accounting and internal control interdependence, management accounting needs data must be supported by internal control, otherwise the authenticity of the data is difficult to ensure. Management accounting is applied to all aspects of internal control, making the design of internal control more reasonable and more effective implementation.

\subsubsection{Information}

In recent years, with the rapid progress and development of related technologies, we have entered the era of big data, artificial intelligence and big data research will also increase. The era of big data provides a platform for the sharing of resources for accounting information, reduces the cost of accounting information and improves the efficiency of accounting information. Relatively speaking, the subject sons of domestic and foreign research are similar but also show different characteristics. The research hotspots of domestic management accounting have long focused on Performance appraisal, performance management, budget management, value chain, strategic management, operating cost method and balanced scorecard. In contrast, foreign scholars on the cost of operation, incentive mechanism and supply chain management research more, the balance of scorecards and so on is not very concerned. Moreover, the research on performance management and management control at home and abroad is more important, but there are some differences in the scope and depth of the two studies.

Research on the impact of management accounting on decision-making will continue. Sprinkle et al. (2008) investigate how the way employees' behavior and performance are monitored, measured, evaluated, and rewarded affects their 
behavior. In analyzing the impact of management accounting on decision making, Bol (2008) proposed a new research topic-preference for subjective performance evaluation and its effect on employee effort. The research results of Chen et al. (2016) show that when managers are aware of the performance indicators related to strategy, rather than simply presenting these indicators to managers, these performance indicators play an important role in making better decisions.

One of the contemporary research themes of management accounting is the study of management accounting in its inter-organizational context, such as strategic alliances, joint ventures, and supply chains, which is the basis for the establishment of a management accounting knowledge system. Schloetzer (2012) studied whether the potential for holding up in supply chains affected the degree of process integration and information sharing among partners, and the results showed that if the partners wanted to carry out more extensive supply chain integration practices, the potential of locking might limit the performance advantages they could gain from it. The study of management accounting using behavioral economics has become a research topic. Luft and Shields (2009) demonstrate how management accounting affects the tradeoff between the utility of monetary income and the utility of non-monetary income for individuals.

\subsection{Methods}

Wu (2012) finds that in the management accounting research method, the management accounting theory research method mainly includes: normative research, investigation, field research, case study, experimental methodology, in recent years, the management accounting theory research at home and abroad began to use: eye tracker technology, neural network technology. In recent years, the experimental methodology is rarely used in the research literature of our country, and most of the experimental designs of some existing literatures are referenced abroad, and the value of experimental methodology is far from being played out.

You can see from Figure 1. In recent years, experimental methodology has become a relatively important method in the western management accounting research, many scholars have made many valuable achievements in the use of this method, while China's management accounting researchers rarely dabbled in experimental methodology field, the existing accounting research literature experiment design is also mainly to copy the methods developed by foreign scholars. China's research on management accounting relies more on the questionnaire method, and the experimental methodology method has its own advantages, the development of experimental methodology method is imperative for our country.

The research topics involved in the study of accounting behavior using experimental methods are becoming more and more diversified. Because of the characteristics of management accounting research, it is difficult for researchers to use archival data or field studies to evaluate the impact of an organization's management accounting system on the behavior of its members in isolation or with other variables. The experience of archives and on-site research in management 
accounting are often accompanied by methodology and measurement problems. Controlled laboratory experiments can overcome these problems, allowing researchers to answer questions with uncertain answers. In addition, experiments are useful complements to analytical work. Although behavioral analysis models provide an excellent framework for evaluating the value and demand of management accounting procedures, they are often criticized for unrealistic assumptions, highly patterned environments, and complex solutions. Experimental methods allow for rigorous testing of theoretical predictions, behavioral validity and assumptions. Given the inherent elasticity of the experimental method, the researchers can push the model's qualification, test the boundary conditions, test the progress of the competition theory and provide evidence of why the actual behavior deviates from the economic model prediction.

This paper further analyzes the application of research methods in various research topics, because the sample selected in this paper only includes experimental methodology, questionnaires and case studies, previous research has found that in China's management accounting research, conceptual research methods or normative analysis in various research topics are the most widely used, The proportion of foreign experimental methodology method is relatively large, and the case study is relatively small both at home and abroad.

From Figure 1, overall, the questionnaire method is most widely used, and the results of Table 3 show that different research methods are more evenly distributed among different topics.

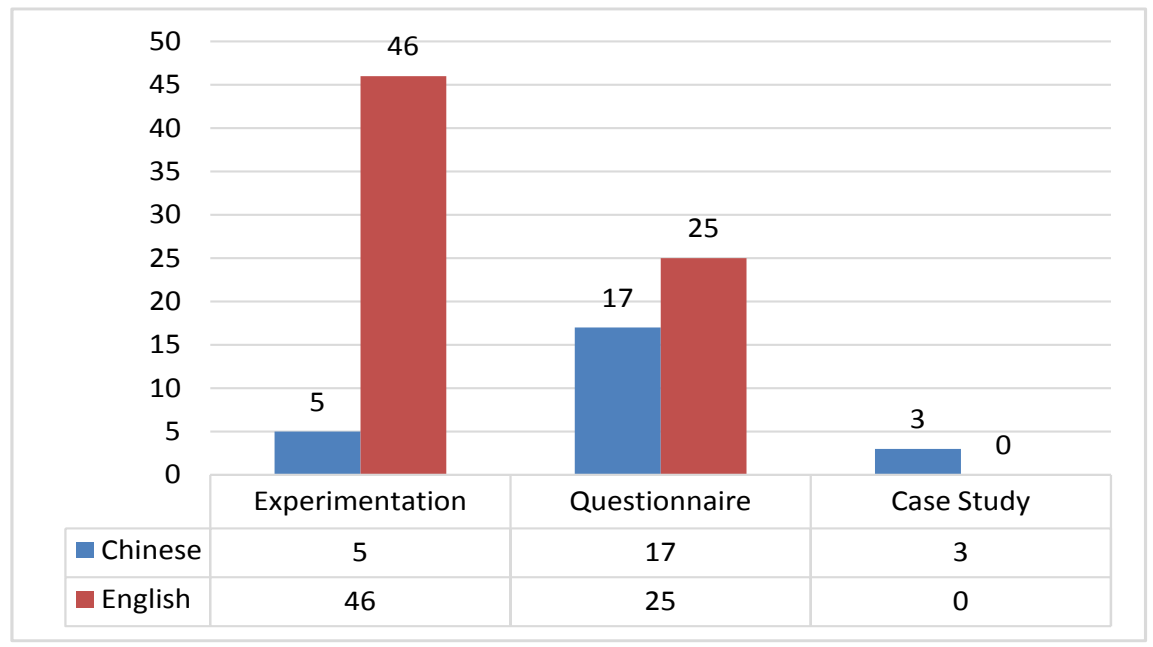

Figure 1. The use of literature research methods in the last three years at home and abroad.

Table 3. Distribution of research methods for different research topics.

\begin{tabular}{ccccc}
\hline Topics & $\begin{array}{c}\text { Management control } \\
\text { system }\end{array}$ & $\begin{array}{c}\text { Cost } \\
\text { management }\end{array}$ & $\begin{array}{c}\text { Budget } \\
\text { management }\end{array}$ & $\begin{array}{c}\text { Strategic } \\
\text { management }\end{array}$ \\
\hline Questionnaire & 17 & 7 & 8 & 10 \\
Experimental & 26 & 3 & 11 & 11 \\
Case study & 0 & 1 & 0 & 2 \\
\hline
\end{tabular}




\subsection{Application Theory}

Like the theory applied in western experimental methodology institutes, China has gradually extended and intersected in the application of theory, but the dominant application theory is different. Wang (2013) statistics show that psychology was in an absolute position (61\%) and relatively low (26\%) on economics, and had the lowest application of sociology (13\%) in the theory that the Western Institute of Management Accounting Experiment relied on from 1991 to 2010. Most of the experimental methodology of management accounting in China is based on economics, and in recent years, psychology and sociology theory have been gradually introduced. Meng et al. (2014) statistics show that from 2006 to 2013, experimental methodology applied economic theory as high as $70 \%$, psychology accounted for $20 \%$, other non-application theory.

In recent years, China's management accounting research is more theoretical, Meng et al. (2014) found that the experimental methodology using the theoretical ratio is the highest, database-based empirical research using the theory of the proportion of the second, normative analysis/conceptual research ratio is the lowest.

This paper divides the theoretical sources of management accounting research in 2015-2017 into economic theory, psychology theory and sociological theory, and the results show that the main theoretical sources of management accounting research in China are applied and economic theory (42.1\%), sociological theory (37.5), and the proportion of applied psychology theory (19.5) His various theories are (3.9\%), while foreign management accounting research is more inclined to economic theory and psychological theory, relatively speaking, domestic management accounting research also takes economic theory as the main source, the application of psychology and sociology theory is significantly low.

In this paper, the specific theory of management accounting research using theory is calculated only one step, and the results show that 94 management accounting literatures using theory use 16 specific theories. This paper is listed in the top 6 theories according to the proportion of various theoretical applications, see Table 4. Statistical results show that the top six theories with the highest

Table 4. Key specific theorist for the application of management accounting research.

\begin{tabular}{|c|c|c|c|c|c|}
\hline Rank & Theory & Counts & Rank & Theory & Counts \\
\hline 1 & Agent theory & $11(45.8 \%)$ & 1 & Agent theory & $32(45.1 \%)$ \\
\hline 2 & Contingency Theory & $6(25 \%)$ & 2 & $\begin{array}{c}\text { Contingency } \\
\text { Theory }\end{array}$ & $9(12.7 \%)$ \\
\hline 3 & Tournament Theory & $1(4.2 \%)$ & 3 & $\begin{array}{c}\text { Tournament } \\
\text { Theory }\end{array}$ & $6(8.5 \%)$ \\
\hline 4 & $\begin{array}{c}\text { Asymmetric } \\
\text { Information theory }\end{array}$ & $1(4.2 \%)$ & 4 & $\begin{array}{c}\text { Asymmetric } \\
\text { Information theory }\end{array}$ & $4(5.6 \%)$ \\
\hline 5 & Stakeholder Theory & $1(4.2 \%)$ & 5 & Stakeholder Theory & $3(4.2 \%)$ \\
\hline 6 & Contract Theory & $1(4.2 \%)$ & 6 & Contract Theory & $1(1.4 \%)$ \\
\hline
\end{tabular}


frequency are agency theory, power change theory, championship theory, information asymmetry theory, stakeholder theory and contract theory, and the application of these six theories reached 76 literatures, accounting for $80.9 \%$ of the 94 literatures of all application theories. In particular, the application of agency theory literature reached 43 , accounting for $45.7 \%$ of all applied theoretical literature, and the agency theory has been mostly used in the management control system Performance appraisal and performance-oriented compensation system research.

\section{Research Methods}

Chinese literature by Gan, to conform to the scientific measurement principle, make the research conclusion more timely, this paper has chosen six management accounting mainstream journal, in the process of selection to eliminate the impact factor journals, research methods only selected the experiment research, questionnaire and case study, the final sample size for a total of 24 piece of literature. Foreign literatures are mainly selected from the top seven accounting journals. Through reading, the literatures conforming to the research theme of management accounting are screened out. The literatures distributed by three research methods are selected, and the final sample size is 71 . A total of 95 articles have been published on management accounting in recent three years. The results are showing in Table 5 and Table 6.

Table 5. Didstribution and number of Chinese literature journals.

\begin{tabular}{cccc}
\hline Journal Name & Counts & Journal Name & Counts \\
\hline Accounting Research & 14 & Management World & 4 \\
Economic research & 2 & Social Sciences in China & 1 \\
Financial Research & 0 & Journal of Management Sciences in China & 3 \\
\hline
\end{tabular}

Table 6. Didstribution and number of English literature journals.

\begin{tabular}{cccc}
\hline Journal Name & Number & Journal Name & Number \\
\hline $\begin{array}{c}\text { Journal of Accounting Research } \\
\text { Journal of Accounting and } \\
\text { Economics }\end{array}$ & 0 & Review of Accounting studies & 0 \\
Accounting Review & 21 & Accounting and Business Research & 1 \\
Accounting Organizations \\
and Society
\end{tabular}

\section{Conclusion}

Through the comparative analysis of management accounting research at home and abroad in the three years from 2015 to 2017, it is found that although China has made great progress compared to the previous period, there is a big gap compared with the subject background of research methods and applied theory 
in foreign countries, and the "promote the basic theory of management accounting" mentioned in the Opinion, The concept framework and tool method research, the formation of the Chinese characteristics of the management accounting theory system" goal also has a large gap, which also provides the future research of management accounting in China:

\subsection{Building a Theoretical System Based on the Practice of Chinese Enterprises}

Throughout the course of management accounting development over the past 30 years, China has "also followed up", introduced, digested and practiced western management accounting theory and methods, and has never completely got rid of the "Tang monk"-style management accounting practice. In 2014, after the Ministry of Finance made management accounting the focus of accounting development, it issued the "Management Accounting Case Guide" and "Management Accounting Practice Guide", and many "typical" cases of management accounting practice emerged in China. With the development of China's market economy, management accounting problems based on China's management situation are the theme of the world. In view of this, China's accounting academic circles must also change their ideas, should put an end to the "era of imitation research", "tracking research" and "improved research" and move into the "era of original research" to provide international accounting circles with high-level research results that highlight Chinese characteristics; To integrate the research results of Chinese management accounting theory into the mainstream of world knowledge.

Unlike financial accounting, management accounting has four dimensions: technology, organization, behavior and situation. In addition to the technical dimensions, the three dimensions of organization, behavior and situation have distinct characteristics of "localization", which reflects the unique institutional and cultural background of China. In layman's terms, $\mathrm{Hu}$ (2017) approves that management accounting is a kind of cognition and practice based on management situation. "Management situation" fully embodies the characteristics of "localization".

As long as the theoretical researchers of management accounting theory go deep into the management practice, we can find many practical problems worthy of study, so as to extract the research topics that show Chinese characteristics. At the same time, if the problems of management accounting research come from management practice, therefore, the academic circles of management accounting in China should cooperate more closely with the practical circles. Academics get the theme sits and inspiration from the practice circle, and solve the problem of management accounting practice in practice through the research of academic circles. In this way, the theoretical research of management accounting is unified with the practical needs, and to a certain extent, it solves the problem of research materials or data sources. 
The study of Chinese management accounting theory should not only show Chinese characteristics, but also integrate into the mainstream of world knowledge, we must establish the concept of "localization of research problems, research methods and internationalization of research paradigms". Only "localization of research issues" can China's research results show Chinese characteristics, and only "research methods and research paradigm internationalization", China's research results can be integrated into the world's mainstream knowledge. Therefore, the study of management accounting theory in China urgently needs a group of research talents who understand both the management situation of China and the rules generally recognized by the international academic community, can accurately grasp the development trend and vein of the international academic circles, and can use the international common research language and research paradigm.

\subsection{Improve the Theory of Management Accounting Research}

Although the research topic of management accounting is closer to the practical content, but as an academic research, management accounting research should be theoretical. In contrast, nearly half of the domestic management accounting research did not find a clear theoretical source, only the description of the concept of practical or management accounting, did not rise to the height of theory. In addition, in the specific application of the theory, the domestic research is still based on economic theory, especially the agency theory, the application of sociology and psychology of management accounting research is less. In this paper, in order to implement the goal of "forming the theoretical system of Chinese special color management accounting" in the Opinions, China's management accounting research should not be limited to "social practice" or "economic behavior", but should be combined with China's socio-economic situation and cultural background, according to the object sitter and problems of the appropriate theory and even build based on The management accounting theory of Chinese background enhances the theoretical, academic and international nature of management accounting research.

At present, most of china's management accounting experiments are based on experimental economics design experiments, derived from the western experimental economic theory is based on information economics and entrusting agents and other classical economic theoretical basis, which has obvious advantages for the study of compensation incentives and budget issues based on explicit or implicit contracts. However, for the management accounting research topic based on individual or group motivation, it may be difficult to capture the choice motivation and psychological response of individual or group decision-making behavior from the perspective of economics. In addition, the excessive pursuit of the complexity of experimental design makes the experimental design obscure and reduces the test ingestion of experimental methodology. In recent years, the research of management accounting in our country has gradually introduced the 
theory of psychology and sociology, and the study of the integration of management accounting and psychology or sociology is one of the important trends in the development of management accounting research. Therefore, the experimental methodology based on the perspective of psychology or sociology should be an important part of the research of management accounting experiment in our country, especially the design of management accounting experiment from the psychological perspective is simple and direct, which can make up the defects of management accounting experiment based on experimental economics, and in the future research. How to combine the experimental design of psychological and sociological perspectives is a problem that domestic scholars should think about.

\subsection{Improving the Scientific and Diversity of Research Methods}

Domestic management accounting research is based on database-based empirical research and normative research, in recent years, case studies and research has been applied to a certain extent. However, compared with the mainstream management accounting research in foreign countries, the application of case studies, research and experimental methodology methods is less. Case study can be carried out in depth for individual enterprises, systematically summarize the success or failure of individual enterprise management accounting implementation and the reasons, refine management accounting tools, which will provide the most basic research materials and results for the management accounting concept framework and theoretical system with Chinese characteristics; The investigation and research provide stake support for management accounting research, which can understand the current situation of management accounting development in China from a macro perspective and verify the important theoretical topic of management accounting. For those who find it difficult to find samples for research but important management accounting research topics, experimental methodology methods are particularly important. Therefore, in order to implement the requirements of the Opinions, China's management accounting research should strengthen the application of case studies, investigation and experimental methodology methods, according to different research topics, reasonable selection of research methods, improve the scientific and diversity of research methods, to ensure the realization of the "Opinion" of the management accounting research objectives.

Researchers in our country need to expand the selection of experimental methodology topics. At present, in the research of management accounting experiment in our country, most of the topics are concentrated in the two management control sub-areas of budget and compensation (such as the research of Cai Zhiming, Zhang Zhaoxuan, Cheng Xinsheng, Wu Grain, Liu Ying and others), and few scholars use behavioral experimental methods to study Performance appraisal and cost control. And these problems have been the focus of the western management accounting experiment research topic. The narrow range of 
topic selection makes it difficult for experimental methodology methods to become the mainstream method of empirical research of management accounting in China, as is the questionnaire method. In fact, the analysis of the subject of foreign management accounting experiment shows that as long as the sample selection is suitable, the experimental design is reasonable and effective, and the experimental methodology method can be used in most research fields of management accounting. However, due to the uncertainty of the development of the questionnaire methodology scale, the attitude and psychological burden of the respondents to fill the questionnaire, the difficulty of sampling in the company's high-level survey, and the self-selecting behavior of the researchers using the questionnaire method, the interpretation effectiveness of the questionnaire empirical test results was discounted to some extent. The experimental methodology method can overcome the above defects, so the experimental methodology of management accounting in our country should further broaden the research topic, so that the experimental methodology method becomes a good supplement to the empirical research method of the investigation.

The experimental design of the management accounting experimental methodology literature in our country mostly refers to the relevant foreign literature, so in the sample selection, experimental procedure programming and statistical analysis methods, the same as the foreign research literature. But perhaps out of the consideration of experimental cost, the sample selection of the management accounting experimental literature in Our country is mainly for undergraduates, and very few literatures (such as the research of Zhang Chaoxuan et al.) have chosen to participate in the experiment with practical work experience, which may make the experimental conclusion difficult to be persuasive. In the relevant management accounting experiment literature in China, it is rarely mentioned that giving the material compensation incentive to the subject is very good at simulating the real enterprise environment (especially in the study of compensation incentive), and can stimulate the subject to participate better in the experiment, avoid the randomness of the test selection and the boredom of the experiment (in fact, the material compensation incentive) that is, the Hawthorn effect), which in turn improves the test effectiveness of the experiment. In addition, in terms of institutional background, cultural environment, as well as the values of the experimental participants and the sense of identity to the organization, the Chinese experimental participants and the Western experimental participants may be very different, and copying the experimental design procedures abroad may lead to the bias of the empirical results, so how to integrate more into the design of management accounting experiments in our country. "Chinese element" is also a question that relevant scholars should focus on.

\section{Conflicts of Interest}

The author declares no conflicts of interest regarding the publication of this paper. 


\section{References}

Bol, J. C. (2008). Subjectivity in Compensation Contracting. Journal of Accounting Literature, 27, 1-24.

Chen, X. Y., \& Huang, J. (2016). Equity Split Reform, Equity Hierarchy and Corporate Performance. Accounting Research, 1, 56-62.

Chen, Y., Jermias, J., \& Panggabean, T. (2016). The Role of Visual Attention in the Managerial Judgment of Balanced-Scorecard Performance Evaluation: Insights from Using an Eye-Tracking Device. Journal of Accounting Research, 54, 113-146. https://doi.org/10.1111/1475-679X.12102

Du R. R., Xiao Z. Z., \& Zhou, Q. W. (2009). A Review of Chinese Management Accounting Research. Accounting Research, 9, 74-80.

He, L. L., Zhu, F. M., \& Chen, Z. W. (2014). Corporate Environmental Responsibility Definition and Evaluation: The Perspective of Environmental Resource Allocation. Management World, 3, 180-181.

Hesford, J. W., Lee, S. H., Van der Stede, W. A., et al. (2006). Management Accounting: A Bibliographic Study. Handbook of Management Accounting Research, 1, 3-26. https://doi.org/10.1016/S1751-3243(06)01001-7

Hu, Y. M. (2011). The Research Framework for Accounting Theory and Methodology in Enterprise Management: Basic Conception and Expected Breakthrough. Communication of Finance and Accounting, 4, 6-10.

Hu, Y. M. (2017). Research on China's Management Accounting Research: Return to Nature and Common Sense. Financial Research, 3, 14-21.

Ji, L., \& Su, M. (2016). Internalization of Enterprise Environmental Cost Drivers: Compliance or Benefits?-Empirical Evidence from Listed Companies in Heavily Polluting Industries. Accounting Research, 11, 69-75.

Liu, Y. G., \& Chen, G. F. (2007). Enterprise Performance Evaluation Study Combining BSC and EVA-Case Analysis Based on GP Enterprise Group. Accounting Research, 9, 50-59.

Luft, J., \& Shields, M. D. (2009). Psychology Models of Management Accounting. Foundations and Trends in Accounting, 4, 199-345. https://doi.org/10.1561/1400000015

Meng, Y., Sun, J., Lu, C., et al. (2014). Review and Outlook of China's Management Accounting Research. Accounting Research, 9, 3-12.

Schloetzer, J. D. (2012). Process Integration and Information Sharing in Supply Chains. The Accounting Review, 87, 1005-1032. https://doi.org/10.2308/accr-10216

Shields, M. D. (1997). Research in Management Accounting by North Americans in the 1990s. Journal of Management Accounting Research, 9, 3-61.

Shields, M. D. (2015). Established Management Accounting Knowledge. Journal of Management Accounting Research, 27, 123-132. https://doi.org/10.2308/jmar-51057

Sprinkle, G. B., Williamson, M. G., \& Upton, D. R. (2008). The Effort and Risk-Taking Effects of Budget-Based Contracts. Accounting, Organizations and Society, 33, 436-452. https://doi.org/10.1016/j.aos.2007.11.001

The Ministry of Finance (2014). Planning the Grand Blueprint to Make History-“The Ministry of Finance on the Overall Promotion of the Management Accounting System Construction Guidance". Series of Interpretation of One of the Series of Journal of Finance and Accounting, 2, 6-10.

Wang, Y. (2013).Application of Experimental Research Methods in Overseas Management Accounting Research-Based on Analysis of Data from 73 Sample Literatures. Journal of Nanjing Audit University, 4, 69-77. 
Wu, X. (2012). Methodology of Accounting Research (pp. 48-68). Beijing: Chinese Min University Press.

Yang, Y. L., Pan, F., \& Zhang, C. (2014). Performance Evaluation of Chinese Enterprises from the Perspective of Differential Order Pattern. Accounting Research, 10, 66-73.

Zhang, C., Yang, Y. L., \& Gao, M. (2012). The Practical Problems and Research Challenges of Non-Financial Performance Appraisal of Chinese Enterprises-Based on Literature Research. Accounting Research, 12, 55-60.

Zhang, X. J., Xu, J., \& Xu, L. B. (2015). Can Executive Elite Governance Model Improve Corporate Performance?-Based on the Regulating Effect of Social Solidarity. Economic Research, 3, 100-114.

Zheng, G. J., Lin, D. J., \& Tan, W. Q. (2016). Clan Control, Group Internal Structure and Performance of Listed Companies. Accounting Research, 2, 36-43.

Zhou, L., Pan, F., Liu, Y.J., \& Ma, B. Z. (2012). Field Research on Management Accounting Changes and Innovation. Accounting Studies, 3, 85-93. 